\title{
Correction to: Response to "A critical look at 'Energy savings, emissions reductions, and health co-benefits of the green building movement"
}

Piers MacNaughton · Xiaodong Cao · Jonathan Buonocore · Jose Guillermo Cedeno-Laurent • John D. Spengler • Aaron Bernstein · Joseph G. Allen

Published online: 20 January 2020

(c) Springer Nature America, Inc. 2020

\section{Correction to: Journal of Exposure Science \& Environ- mental Epidemiology}

https://doi.org/10.1038/s41370-019-0118-5

In the response to Scofield's critique of "Energy savings, emissions reductions, and health co-benefits of the green building movement", MacNaughton et al. wrote, "On closer inspection, of these 27 sources, three are discussed above, and, of the remaining 24 , only 12 are peer-reviewed, five are self-referential (i.e., written by Scofield et al.), and one is cited twice." In this statement, we do not consider 12 of the articles to be peer-reviewed as they were published in conference proceedings rather than peer-reviewed journals. However, the journal considers conference proceedings as peer-reviewed. While the authors disagree with this definition of peer-review, this correction provides the appropriate context about the nature of the publications that were cited in Scofield's response to the original manuscript. 